\title{
AGE AND GENDER MAY INFLUENCE THE RESULTS OF ROUX-EN-Y GASTRIC BYPASS? Metabolic syndrome parameters
}

\author{
Stephan Garcia ANDRADE-SILVA ${ }^{1,4,5}$, Danielle Arisa CARANTI ${ }^{1,3,4}$, \\ José Afonso SALLET ${ }^{5}$, Lucas Pedroso Fernandes Ferreira LEAL,5, \\ Antonio Joaquim Ferreira LEAL ${ }^{5}$ and Ana Raimunda DÂMASO'1,2,3,
}

\begin{abstract}
Context - Severe obesity affects the body favoring the development of serious diseases, including hypertension, diabetes mellitus, atherosclerosis and non alcoholic fatty liver disease. Bariatric procedures increased in Brazil in the last decade. Objectives - The purpose of this study was to verify if gender and age in date of procedure resulted significant differences in metabolic syndrome parameters after surgery. Methods - The study involved 205 medical records of adult patients undergoing Roux-en-Y gastric bypass, stratified by gender and age groups and followed one year by a multidisciplinary team. Results - It was observed significant decrease in body mass index, fasting glucose and insulin at all ages and both genders. Lipid profile showed significant improvements except high density lipoprotein cholesterol. Ectopic fat in the liver has decreased after 6 months in patients classified with steatosis at baseline. Patients classified as hypertensive blood pressure levels decreased 6 months after surgical intervention. Conclusion - Roux-en-Y gastric bypass proved to be an important tool in remission of metabolic syndrome parameters. The reduction of body mass accompanied to decrease in insulin resistance resulted in lower prevalence of comorbidities associated with obesity. The benefits were similar and extended both genders and all age groups between 18 and 65 years old.
\end{abstract}

HEADINGS - Bariatric surgery. Metabolic syndrome X. Roux-en-Y anastomosis. Fatty liver.

\section{INTRODUCTION}

Obesity is rapidly becoming a major public health problem worldwide. It is considered a multifactorial disease since endogenous and exogenous factors are involved in their cause as well as the chronic positive energy balance ${ }^{(31)}$. Epidemiological data indicate an increase in the prevalence of obesity in most countries, developed or developing. The World Health Organization estimates that over one hundred million adults are overweight and 500 million of these are clinically obese ${ }^{(52)}$.

Considered as conventional treatment, the interdisciplinary therapy (diet, exercise, behavior therapy, drug therapy) appears to be as an efficient nonsurgical strategy to reverse the obesity by change in lifestyle ${ }^{(46)}$. However, individuals classified by body mass index (BMI) degree III presents a great difficulty in maintaining weight loss over the long term. In this specific group, the failure of clinical treatment is over
90 percent $^{(14,42)}$. Severely obese patients who shows a significant weight loss by conventional treatment ranges from $5 \%$ to $8 \%$, diminishes this rate near a $1 \%$ or $2 \% 5$ years after the end of treatment. Thus, bariatric surgery is indicated for this group ${ }^{(17)}$.

Of the approximately 200,000 bariatric surgeries performed in 2006, about $80 \%$ were due by Rouxen-Y gastric bypass $(\mathrm{RYGB})^{(49)}$. This technique is the most recommended and used in Brazil and is considered the gold standard procedure for weight loss surgery ${ }^{(9,11)}$.

Patients submitted to gastric bypass should perform blood tests regularly to control possible deficiencies in vitamins and minerals ${ }^{(51)}$. The European Association for Endoscopic Surgery recommends that patients should be clinically evaluated between three and eight times in the first year of surgery, one to four times in the second year and once or twice in subsequent years ${ }^{(39)}$.

Obesity has long ceased to be expressed only in

Declared conflict of interest of all authors: none

${ }^{1}$ Programa de Pós-Graduação Interdisciplinar de Ciências da Saúde da Universidade Federal de São Paulo - UNIFESP, Santos, SP, Brasil; ${ }^{2}$ Programa de Pós-Graduação de Nutrição da Universidade Federal de São Paulo - UNIFESP, São Paulo, SP, Brasil; ${ }^{3}$ Departamento de Biociências da Universidade Federal de São Paulo - UNIFESP, Santos, SP, Brasil; ${ }^{4}$ Grupo de Estudos da Obesidade - GEO, Universidade Federal de São Paulo - UNIFESP, Santos, SP, Brasil; ${ }^{5}$ CliLeal - Clínica Médica e Cirurgia Geral, Santos, SP, Brasil.

Correspondence: Stephan Garcia Andrade-Silva. Universidade Federal de São Paulo - UNIFESP - Grupo de Estudo da Obesidade - GEO. Av. Ana Costa, 178 CEP 11060-001 - São Paulo, SP, Brasil. E-mail: stephangarcia@uol.com.br 
adults. Due to increasing prevalence of childhood obesity, many individuals already enter the adolescent and adulthood with high BMI, associated with diseases triggered by obesity and amounts the number of young adults undergoing to the procedure. The RYGB can promote a massive loss of body weight and possible helps to reduce insulin resistance that is a trigger for various comorbidities associated with obesity, such as non alcoholic fatty liver disease (NAFLD), diabetes mellitus type 2 (DM2), dyslipidemia, cardiovascular diseases among others. The purpose of this study was to evaluate the effects of RYGB on the metabolic and biochemical parameters of obese adults and the role of age and gender on these outcomes.

\section{METHODS}

\section{Study Design}

We performed a retrospective cohort study by collected data of 519 medical records of adult patients undergoing RYGB by CLILEAL Clinic, located in Santos, São Paulo, Brazil. The study was approved by the Ethics Committee in Research of Federal University of Sao Paulo - UNIFESP (\#0449/11) and all patients signed an inform consent.

The procedures occurred between February 2006 to November 2012. All bariatric interventions were performed by the same surgeon and medical staff. We included records of patients who had completed all follow-up protocol for 1 year after surgery. We did not include records of patients operated previously by other techniques, as well as patients who presented complications that led to further surgical procedures or who have engaged in exercises programs.

After applying the criteria for inclusion and non-inclusion, 205 medical records were selected for this study. Most of the patients had BMI class III [with $30(16.8 \%)$ males and $149(83.2 \%)$ females], totaling $87.3 \%$ of the sample. Patients with BMI class II totaled $12.7 \%$ of the sample and were divided in $1(3.8 \%)$ male and $25(96.2 \%)$ females.

The reasons for exclusion of some records were the following: $12(2.3 \%)$ because previous bariatric procedures (all, adjustable gastric band), 27 (5.2\%) re-surgery (hernias, adhesions and stenosis of the anastomosis), $11(2.1 \%)$ were participating in exercise programs and 264 (50.8\%) fail the follow up of the multidisciplinary team.

The database had all the monitoring of patients in relation to anthropometric (height and body mass), clinical (blood pressure (BP)), image (abdominal ultrasonography), and biochemical exams: fasting blood glucose, lipid fractions (total cholesterol (TC), high-density lipoprotein cholesterol (HDL-C), low density lipoprotein cholesterol (LDL-C), Triglycerides (TG), insulin (IN). We observed the baseline profile of patients undergoing Roux-en-Y gastric bypass and compared the results 6 and 12 months after the procedure. Patients were stratified by gender and into five groups according to age (From 20 to 29, 30-39, 40-49, 50-59 and over 60 years, calls group one to five). The anthropometric analysis was performed in eight times (anamnesis, surgery, 10, 20, 60, 90, 180 and 365 days). Serum analyses were performed in three times (pre surgery, 6 and 12 months after, calls baseline, short and long-term respectively).

\section{Methods of the database composition - Antropometrics}

Measures of body mass were performed on a mechanical platform scale, accurate to $0.1 \mathrm{~kg}$ (Filizola ${ }^{\circledR}$ model 300/5). The patients were weighed on foot, barefoot, wearing as little clothing as possible, with outstretched arms at your sides, eyes fixed on a point in front (Frankfurt plane) and moving as little as possible to avoid the oscillations and thus prevent the reading. To measure the height was used a scale stadiometer accurate to $0.1 \mathrm{~cm}($ Sanny®). The patient was positioned on the base of the stadiometer, without shoes, so upright, with their arms at your sides, feet together, trying to make the posterior surfaces of the heels, pelvis, the scapular girdle and occipital region in contact with the measurement scale. With the help of the cursor, it was determined the measure corresponding to the distance between the plantar region and the vertex, the remaining assessed in inspiratory apnea, with his head in the Frankfurt plane parallel to the ground ${ }^{(29)}$. Armed with the measures of body mass and height was calculated BMI, which corresponds to the measurement of body mass in kilograms $(\mathrm{kg})$ divided by height in meters $(\mathrm{m})$ squared.

\section{- Biochemicals analisys}

It was performed by the patients' particular health care plans. It was recommended fasting of 12 hours before the blood collected. Diabetes type 2 was diagnosed considering blood glucose greater than or equal to $126 \mathrm{mg} / \mathrm{dL}$ in fasting test (enzymatic method). The levels of lipid fractions were classified as recommended by the Brazilian Society of Cardiology (TC less than $200 \mathrm{mg} / \mathrm{dL}$ desirable, 200239 borderline, and greater than or equal to 240 , high) by enzimatic colorimetric method. Desirable level of HDL-C greater than $40 \mathrm{mg} / \mathrm{dL}$ for men and $50 \mathrm{mg} / \mathrm{dL}$ for women by spectrophotometric method. Desirable LDL-C less than $130 \mathrm{mg} / \mathrm{dL}$ (calculated using Friedewald equation ${ }^{(19,50)}$ ), and triglycerides below $150 \mathrm{mg} / \mathrm{dL}$ (electrochemiluminescence). Insulin results were used to calculate insulin resistance by Homeostasis Model Assessment (HOMA-IR) estimated by the equation proposed by Matthews et al. ${ }^{(30)}$. The HOMAIR normal limit was set at less than 2.71 proposed by Geloneze and Tambascia ${ }^{(20)}$. The insulin sensitivity was estimated by the Quantitative Insulin Sensitivity Check Index (QUICKI) proposed by Katz et al. ${ }^{(25)}$. The QUICKI's normal limit was greater than 0.357 , as proposed by Hrebicek et al. ${ }^{(22)}$.

The National Cholesterol Education Program from American Heart Association criteria was considered for Metabolic Syndrome (MS) diagnosis. It is composed by five parameters: increased waist circumference, BP, fasting glucose and TG, and low serum HDL-C ${ }^{(45)}$. As waist circumference was not documented routinely in our medical record, we used BMI as a surrogate for central obesity whereas data have shown that most patients with a BMI $\geq 30 \mathrm{~kg} / \mathrm{m}^{2}$ have a large waist circumference ${ }^{(36)}$. 


\section{- Statistics}

A Komolgorov-Smirnov test was used to verify the normality of the variables. For parametric variables, results are presented as mean with standard deviation. Student's $t$ test was used for independent samples comparisons. For categorical variables we used a Pearson's $\mathrm{X}^{2}$. Changes between different time points (most of three paired samples) were analyzed using ANOVA with post hoc tests (Bonferroni - within homogeneity of variances or Games-Howell). Levene's tests was used to verify homogeneity/similarity of variances. Nonparametric variables are expressed in median (minimum - maximum). Mann Whitney's test was used for independent samples comparisons. For categorical variables we used a Spearman's $X^{2}$. Changes between different time points (most of three paired samples) were analyzed using Friedman test. A $P$ value $<0.05$ was considered significant. We used Statistical software PASW 18 (SPSS Inc. Chicago, IL) for analysis.

\section{RESULTS}

\section{Anthropometrics profile}

A total of 205 medical records were analyzed and stratified by gender and age. There was a higher prevalence of females $(n=176,-85.85 \%)$ despite male gender $(n=29$ - 14.15\%). Males presented higher height and bodyweight in all age groups, but the BMI was not statistically different between all groups, both age and gender (Table 1).

After 12 month follow-up, we observed a massive loss of body weight and BMI $(P<0.001)$. The body weight response and BMI consequently were statistically similar between genders $(P<0.185)$. All age groups reduced significantly body weight and BMI $(P<0.001)$. The groups $1,2,5$ and the females of group 4, reached BMI classified as overweight. The prevalence of BMI degree 3 decreased from $88 \%$ to $2 \%$ of patients. Concomitant to this, $9 \%$ of patients were eutrophic and $48 \%$ were classified in overweight (Figure1).

TABLE 1. Descriptive anthropometrics profile of patients undergoing a Roux-en-Y gastric bypass

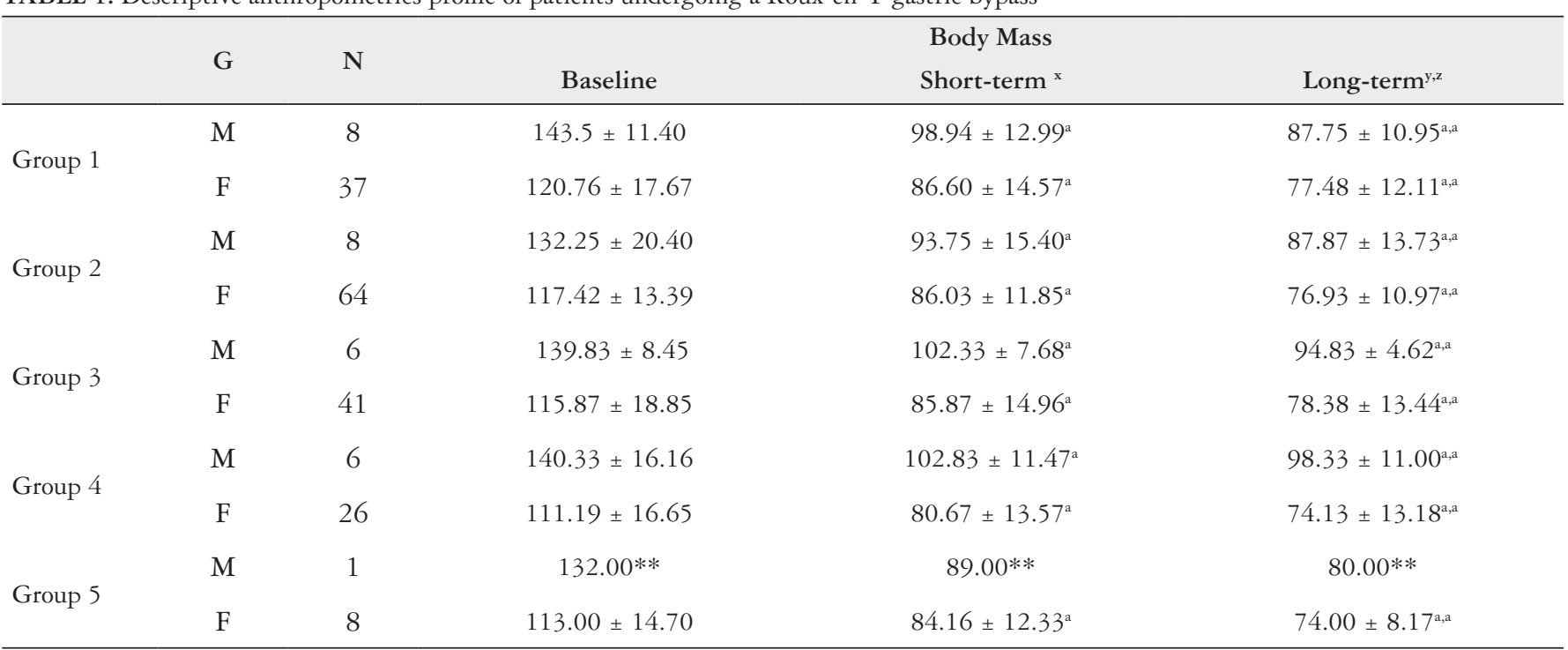

Values expressed by mean \pm SD. G: Gender; M: male; F: female; Group 1=Age 20-29; Group 2=Age 30-39; Group 3=Age 40-49; Group 4=Age 50-59; Group 5=Age over 60. ** Not expressed because only one case; ${ }^{\mathrm{x}}$ Baseline x Short-Term; ${ }^{\mathrm{y}}$ Baseline x Long-Term; ${ }^{\mathrm{z}}$ Short-Term x Long-Term; ${ }^{\mathrm{a}} P<0.001$

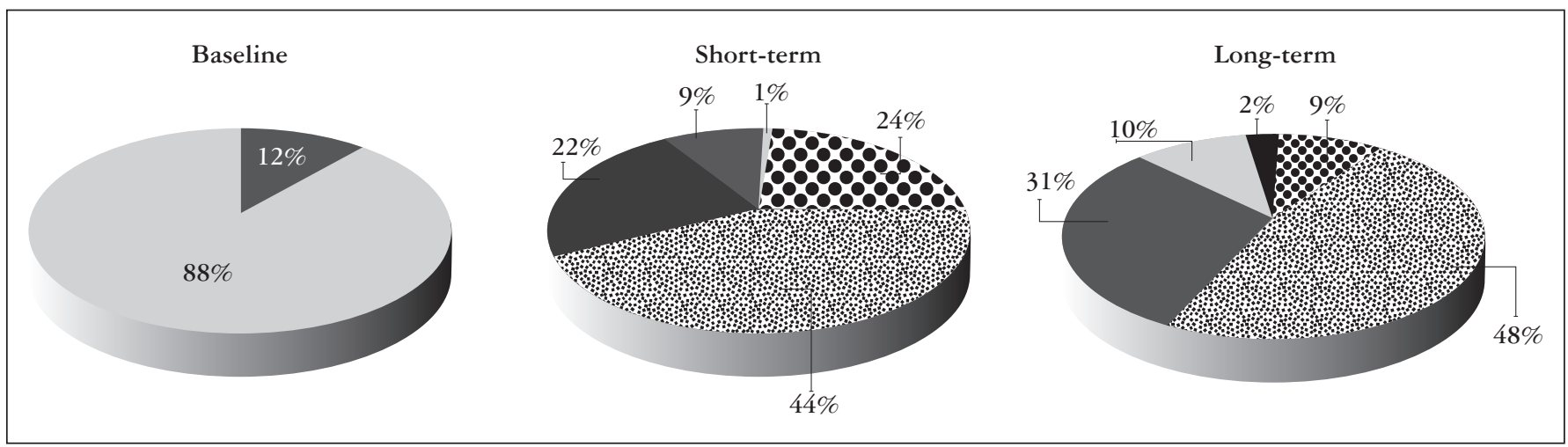

FIGURE 1. Patients profile submitted at Roux-en-Y gastric bypass at baseline, short and long-term, classified by BMI $(P<0.001)$. 
One year after the procedure, males had $68.2 \%$ of the excess weight loss ( $\%$ EWL), a similar amount shown by females $(P<0.753)$. The $\%$ EWL among males was not significantly different from the females in all measures of follow-up (Figure 2).

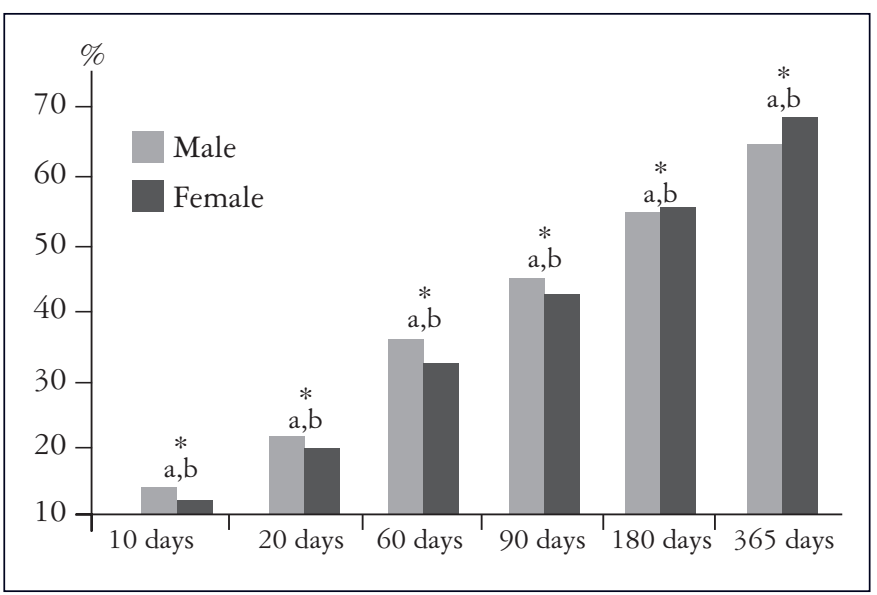

FIGURE 2. Comparison of excess of weight loss (\%EWL) between genders alter one year of the gastric bypass.

"indicates similarity between genders $(P<0.753)$.

aindicates significance compared to preoperative values $(P<0.001)$.

bindicates significance compared to previous evaluation $(P<0.001)$.

\section{Image profile}

Ultrasonographic exams previous surgery revealed a prevalence of $35.2 \%$ of patients $(9.8 \%$ males $/ 25.4 \%$ females, $P<0.001)$ with NAFLD. Stratified by disease's degrees, $25.9 \%$ had grade 1 (6.4\% males / $19.5 \%$ females), $6.8 \%$ grade $2(2.0 \%$ males / and $4.8 \%$ females), and $2.4 \%$ had grade 3 (1.4\% males $/ 1.0 \%$ females). The patients in grade 3 were monitored through imaging, and all showed remission to minor degrees of disease after 6 months from surgery. Females presented higher NAFLD prevalence than males, but in grade three males presented greater prevalence $(P<0.01)$.

\section{Metabolic profile}

The results of blood tests of patients before surgery revealed a high prevalence of comorbidities associated with obesity. From the medical records of patients enrolled, 32.2\% had abnormal fasting glucose. Among these, $11.71 \%$ had DM2, 92.2\% had altered QUICKI index, 79.0\% had HOMAIR altered, $13.5 \%$ had increased TC levels, $47.2 \%$ had HDL-C diminished, and $68.3 \%$ had increased LDL-C, $47.8 \%$ had TG above normal levels and $53.7 \%$ had hypertension or used antihypertensive drugs. These data showed a prevalence of $52.7 \%$ of patients presenting criteria for metabolic syndrome according to NCEP criteria. All parameters with the exception of HDL-C were statistically significant improvements after 1 year Roux-en-Y gastric bypass (Table 2).

\section{Glicemic Insulinemic response}

At baseline, patients of groups 3, 4, 5 presented higher levels of fasting blood glucose than groups 1 and two $(P<0.013)$. Groups 1 and 2 presented similar levels at baseline $(P<0.862)$. In group 3 and 5 , females had higher levels than males $(P<0.001)$. A reverse situation was observed in group $4(P<0.001)$. At short-term, all groups, with exception of females in group 5, presented significant improvements, reaching recommended levels. In long-term, all age groups and both genders presented normality levels of fasting blood glucose. Groups 1 and 2 had a significant improvement between short and long-term. This improvement was not observed in other groups.

Fasting insulin had significant improvement in all age groups and both genders at short-term. This improvement was continuous at short and long-term, with exception in females of group 5, in which this decrease was not statistically significant, although continuous improvement.

The improvement in insulin and fasting glucose, the insu-

TABLE 2. Prevalence of comorbidities before and after gastric bypass

\begin{tabular}{|c|c|c|c|c|c|c|c|c|c|c|c|c|c|c|c|}
\hline \multirow{3}{*}{ Group 1} & \multirow{3}{*}{$\begin{array}{c}\text { Gender } \\
\mathrm{M}\end{array}$} & \multicolumn{7}{|c|}{ QUICKI } & \multicolumn{7}{|c|}{ HOMA-IR } \\
\hline & & \multicolumn{3}{|c|}{ Baseline } & \multicolumn{4}{|c|}{ Long-term $^{\mathrm{y} . \mathrm{z}}$} & \multicolumn{3}{|c|}{ Baseline } & \multicolumn{4}{|c|}{ Long-term ${ }^{\mathrm{y} . \mathrm{z}}$} \\
\hline & & 0.317 & \pm & 0.015 & 0.386 & \pm & 0.015 & $\mathrm{a}, \mathrm{a}$ & 3.70 & \pm & 1.04 & 0.99 & \pm & 0.23 & $\mathrm{a}, \mathrm{a}$ \\
\hline & $\mathrm{F}$ & 0.321 & \pm & 0.042 & 0.402 & \pm & 0.028 & $\mathrm{a}, \mathrm{a}$ & 4.13 & \pm & 1.95 & 0.87 & \pm & 0.42 & $\mathrm{a}, \mathrm{a}$ \\
\hline \multirow[t]{2}{*}{ Group 2} & M & 0.303 & \pm & 0.029 & 0.376 & \pm & 0.019 & $\mathrm{a}, \mathrm{a}$ & 6.57 & \pm & 5.17 & 1.17 & \pm & 0.38 & $\mathrm{a}, \mathrm{a}$ \\
\hline & $\mathrm{F}$ & 0.315 & \pm & 0.026 & 0.387 & \pm & 0.026 & $\mathrm{a}, \mathrm{a}$ & 4.42 & \pm & 2.10 & 1.04 & \pm & 0.41 & $\mathrm{a}, \mathrm{b}$ \\
\hline \multirow[t]{2}{*}{ Group 3} & M & 0.311 & \pm & 0.026 & 0.370 & \pm & 0.023 & $\mathrm{a}, \mathrm{d}$ & 5.32 & \pm & 4.57 & 1.33 & \pm & 0.52 & $\mathrm{a}, \mathrm{b}$ \\
\hline & $\mathrm{F}$ & 0.305 & \pm & 0.027 & 0.387 & \pm & 0.027 & $\mathrm{a}, \mathrm{b}$ & 5.86 & \pm & 3.28 & 1.07 & \pm & 0.52 & $\mathrm{a}, \mathrm{a}$ \\
\hline \multirow[t]{2}{*}{ Group 4} & $\mathrm{M}$ & 0.289 & \pm & 0.029 & 0.377 & \pm & 0.022 & $\mathrm{a}, \mathrm{c}$ & 9.78 & \pm & 7.53 & 1.18 & \pm & 0.48 & $\mathrm{a}, \mathrm{d}$ \\
\hline & $\mathrm{F}$ & 0.302 & \pm & 0.021 & 0.382 & \pm & 0.027 & $\mathrm{a}, \mathrm{c}$ & 5.98 & \pm & 3.46 & 1.18 & \pm & 0.75 & $\mathrm{a}, \mathrm{c}$ \\
\hline \multirow[t]{2}{*}{ Group 5} & $\mathrm{M}$ & 0.331 & & $*$ & 0.380 & & * & & 2.57 & & $*$ & 1.02 & & $*$ & \\
\hline & $\mathrm{F}$ & 0.306 & \pm & 0.035 & 0.383 & \pm & 0.022 & $\mathrm{a}, \mathrm{b}$ & 6.61 & \pm & 5.23 & 1.11 & \pm & 0.54 & $c, \mathrm{~d}$ \\
\hline
\end{tabular}

M: Males; F: Females; Group 1=Age 20-29; Group 2=Age 30-39; Group 3=Age 40-49; Group 4= Age 50-59; Group 5=Age over 60.

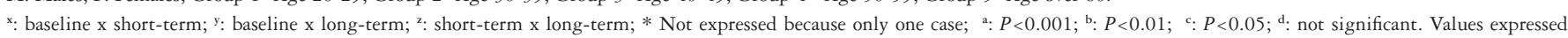
by mean \pm SD 
lin resistance (expressed by HOMA-IR), and insulin sensitivity (expressed by QUICKI), had a significant improvement at short-term in both genders and all age groups. Only in males of group 2, QUICKI had not reached normal values at short-term. In long-term all groups had normal values for QUICKI and HOMA-IR (Table 3).
Response on lipid profile

TC had significant improvement in all groups in the shortterm $(P<0.001)$. Only patients in group 5 did not presented significant improvement between short and long-term.

The results of HDL demonstrated a different response to surgery according to the age group and gender (Table 4).

TABLE 3. Follow-up of sensitivity and resistance of insulin expressed by Quantitative Insulin Sensitivity Check Index (QUICKI) and Homeostasis Model Assessment - Insulin Resistance (HOMA-IR)

\begin{tabular}{|c|c|c|c|c|c|c|c|c|}
\hline & \multicolumn{2}{|c|}{ Baseline } & \multicolumn{2}{|c|}{ Short-term } & $P^{*}$ & \multicolumn{2}{|c|}{ Long term } & $P^{* *}$ \\
\hline Diabetes Mellitus 2 & 24 & 11.71 & 3 & 1.46 & $<0.001$ & 0 & 0.00 & $<0.001$ \\
\hline HOMA-IR Altered & 162 & 79.02 & 18 & 8.78 & $<0.001$ & 1 & 0.49 & $<0.001$ \\
\hline Total Cholesterol elevated & 28 & 13.66 & 1 & 0.49 & $<0.001$ & 0 & 0.00 & $<0.001$ \\
\hline HDL-C Altered & 97 & 47.32 & 116 & 56.59 & $<0.055$ & 105 & 51.22 & $<0.223$ \\
\hline Metabolic syndrome & 108 & 52.68 & 49 & 23.90 & $<0.001$ & 17 & 8.29 & $<0.001$ \\
\hline Arterial hypertension & 110 & 53.66 & 72 & 35.12 & $<0.010$ & 71 & 34.63 & $<0.010$ \\
\hline
\end{tabular}

$* P$ value between baseline $\mathrm{x}$ short-term; $* * P$ value between baseline $\mathrm{x}$ long-term

TABLE 4. Results of high density lipoprotein cholesterol after Roux-en-Y gastric bypass stratified by age groups.

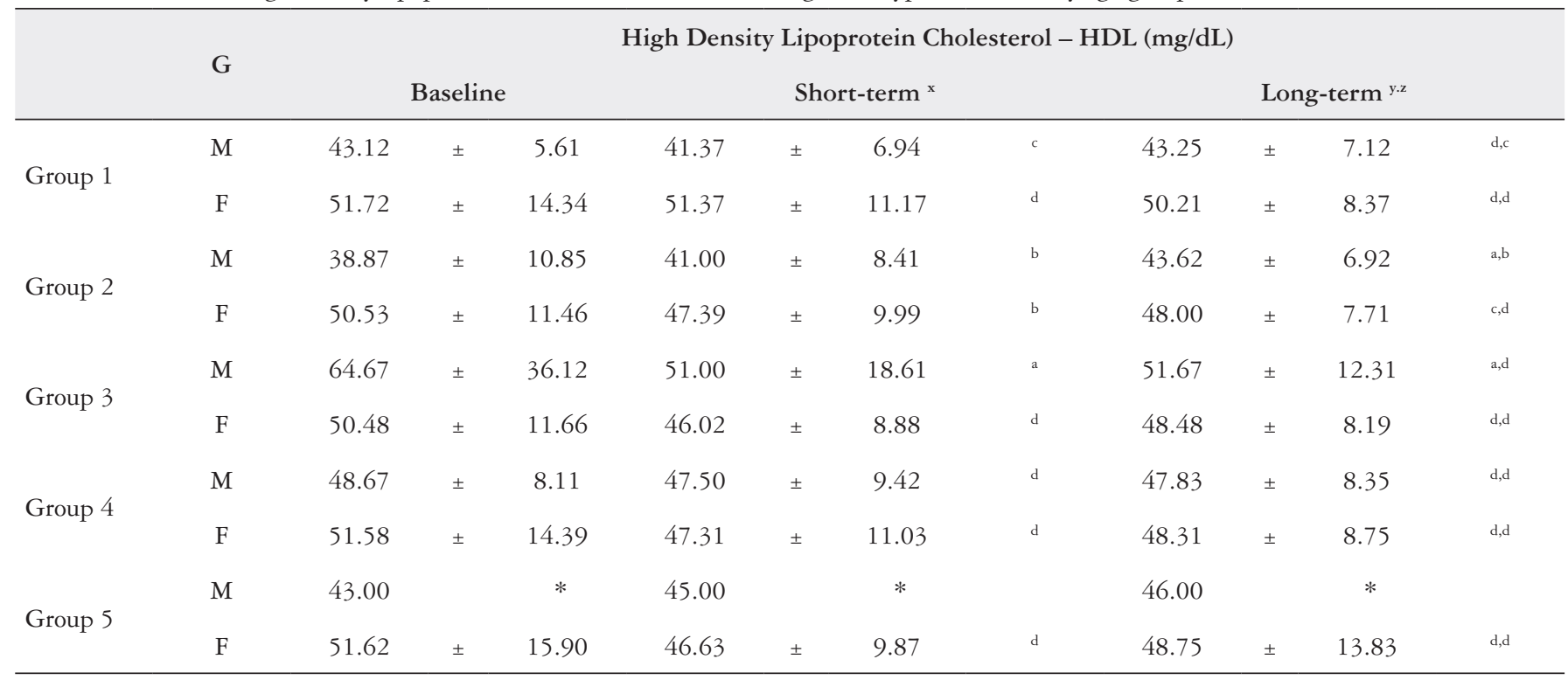

G=Gender; Group 1=Age 20-29; Group 2=Age 30-39; Group 3=Age 40-49; Group 4=Age 50-59; Group 5=Age over 60 .

${ }^{\mathrm{x}}$ : baseline $\mathrm{x}$ short-term; ${ }^{\mathrm{y}}$ : baseline $\mathrm{x}$ long-term; ${ }^{\mathrm{z}}$ : short-term $\mathrm{x}$ long-term; $*$ not expressed because only one case; ${ }^{\mathrm{a}}: P<0.001 ;{ }^{\mathrm{b}}: P<0.01 ;{ }^{\mathrm{c}}: P<0.05$; ${ }^{\mathrm{d}}:$ not significant.

Values expressed by mean \pm SD 
All groups had statistically significant reduction of LDL-C in the short term. Despite the significant reduction, the males of group 4 had not desirable values of LDL-C in this period. In the long-term, the values continued improving and all groups had values considered desirable.

The TG presented a significant improvement in all groups in short-term and also in long-term. Desirable TG levels were reached in short-term in all groups. These values continued improving between short and long-term except for females in group 5, which did not achieved significant improvement in this period.

\section{DISCUSSION}

The benefits of bariatric surgery, with improvement in parameters of the metabolic syndrome, have been long the object of study by several authors ${ }^{(1,2,6,12,42)}$. Few studies have aimed to observe the differences between genders and age groups after bariatric surgery. It is know that women most frequently seek this procedure ${ }^{(7,16)}$.

In our study we observed differences between age groups and genders on the anthropometrics responses, biochemical's exams and metabolic parameters in adults undergoing RYGB. After surgery individuals presents decrease in body mass because of their restrictive and disabsorptive factors. We hypothesize that the newest age may be a factor of better results after procedure.

In this study we observed several differences when the patients were stratified by age and gender after Roux-en-Y gastric bypass. There was female predominance $(85.85 \%)$ as opposed to males $(14.15 \%)$. Body weight before surgery was higher in males. Males tend to be strongest and heaviest compared to the females because of larger muscle mass ${ }^{(32)}$.

It was observed a massive loss of body weight with a significant decrease in BMI in both genders and all age groups after surgery. The excess weight loss showed similar between genders within each age group at all times during the monitoring.

A recent study demonstrated that is not appropriate to use non-randomized studies to compare different BMI groups ${ }^{(47)}$. The present study is a retrospective study and it was not possible randomization of patients. However, observing the data of our sample, we found similar BMI before surgery, allowing comparison between groups. In addition, comparing the age groups, no significant differences were found.

Based upon for these findings, we can asseverate that this procedure promotes loss of excess weight independently of sex or age at time of surgery. In fact, studies involving other age ranges, as adolescents and adults over 65 years have been tested with satisfactory outcomes ${ }^{(15,35,54)}$.

Allied to the weight loss we observed a decrease in the prevalence of several comorbidities associated with obesity. Our study showed high prevalence $(32.2 \%)$ of patients with alterations in glucose metabolism. Within this, $11.71 \%$ presented DM2 and 20.49 were classified as glucose intolerant. No difference in prevalence between genders was observed.

In our series, $92.2 \%$ of patients presented QUICKI values diminished at baseline, suggesting changes in insulin action and complications of glycolytic metabolism. After RYGB we observed a decrease in blood glucose and fasting insulin levels. In short-term QUICKI and HOMA-IR were in normal limits independent of age, showing the improvement in glucose metabolism mediated by the action of insulin. In addition, an important result observed in this study is the DM2 complete remission 1 year after surgery.

When stratifying the sample, we observed higher values of fasting glucose in older age groups (groups 3, 4 and 5, $P<0.013)$. These data corroborate with the literature that indicate a higher diabetes incidence after forty years old ${ }^{(5)}$. In these groups, we also observed higher mean values of fasting glucose in women when comparing to men. Women in the older group only reached a significant reduction in blood glucose 1 year after surgery, while groups 1 and 2 had already decreased in the short term, over and maintaining significant decrease between the short and long term as well. The hypothesis of skeletal muscle turnover increased with age, associated with pre-menopause can be the key to these differences. Other studies show higher incidence of DM2 in postmenopausal ${ }^{(13)}$.

The mechanisms capable of promote insulin action after RYGB are still controversial and seem to be independent of the magnitude of weight loss. The action of incretins, particularly glucagon-like peptide-1 (GLP-1), has been extensively studied because they increase insulin secretion and decrease apoptosis of pancreatic beta cells. Besides, GLP-1 is related to slower gastric emptying. This hypothesis is supported by studies indicating to the rapid improvement of insulin action after a week of monitoring, during which mechanisms activated through the weight loss still could not respond satisfactorily. The new anatomy of the digestive system after surgery favors a secretion of GLP-1, the trigger for the improvement of glucose metabolism ${ }^{(24,26,27,38,40,53)}$.

The role of insulin resistance in the development of NAFLD has suggested the inclusion of this as criteria for the classification of metabolic syndrome ${ }^{(10,33)}$. An important finding in our study, was a decrease in prevalence of NAFLD in short-term on patients with disease's grade three. With the massive loss of body mass, it was expected a large amount of free fatty acids through the portal vein which could provide an increase on ectopic fat in the liver. In study on the effects of RYGB on hepatic steatosis, a patient presented reduction in BMI (52 to $24 \mathrm{~kg} / \mathrm{m}^{2}$ ), causing steatohepatitis and liver fibrosis diagnosed by biopsy one year after the procedure ${ }^{(44)}$. We observe a decrease on NAFLD grade on ultrasound examination 6 months after surgery. This decrease, in our view, was due to the correct prescription and monitoring the diet proposed to patients by multidisciplinary team. Perhaps with analysis at less time frame (when the loss of body mass is more intense), could have indicated a temporary increase in the degree of steatosis to steatohepatitis (NASH).

This result has been according with the study of Ribeireiro et al. ${ }^{(37)}$, in which the presence of NAFLD/NASH without portal hypertension were not predictors of complications after surgery. In our study we observed $32 \%$ prevalence of NAFLD, being more common in women between 30 and 50 years. 
Despite the higher prevalence of women with NAFLD, when stratified by gender, we observed males with higher prevalence $(66 \%)$ of NAFLD grade $3(P<0.01)$. In the same way, with Brazilian patients observed by ultrasound, the prevalence of NAFLD in 59\% of the sample, being more common in women in the 4 th and 5 th decades of life ${ }^{(4)}$. Ultrasound is not a gold standard for diagnosis of NAFLD but has a lower cost and non invasive access providing follow-up with liver biopsy in cases which present more severe degrees of the disease ${ }^{(28)}$.

Insulin, an anabolic hormone, contributes to the synthesis and mobilization of free fatty acids in adipose tissue, increasing the uptake of triglycerides by adipocytes and impairs glucose metabolism. This permanent hyperglycemia results in higher peripheral insulin resistance. The increased synthesis of triglycerides in the liver and decreased production of HDL-C may trigger dyslipidemia as well as more susceptibility to atherosclerosis. This sense, the decrease of insulin and glucose favors the improvement of lipid profile after bariatric surgery ${ }^{(41)}$.

In the present study, it was observed an improvement in lipid fractions after bariatric bypass. The results revealed a decrease in total cholesterol levels, LDL-C and triglycerides. Total cholesterol decreased significantly in both genders and age groups. After 1 year all patients had total cholesterol levels within the normal reference. Our results follow the observations already arranged in the literature ${ }^{(23)}$.

The fractions of LDL-C and triglycerides decreased significantly in short and long term, but showed no significant difference between age groups and gender in response to surgery. It seems to be a common pattern that the effects on lipid fractions occur much more gradual than those found in glucose metabolism, for example. Several studies show a gradual improvement of the lipid fractions and suggests that the highest levels are found only 2 years after the procedure ${ }^{(23,34)}$.

In contrast of other lipid fractions the effects of gastric bypass on HDL-C showed different and conflicting results between genders and age groups. Some authors suggest that the response of HDL-C is represented graphically by a " $U$ " curve-shaped, with a decrease in the first month and a gradual increase after 6 months of surgery ${ }^{(3,23)}$. In fact, the average values found in our study groups suggest the formation of this curve, but in a discreet manner and with values with- out statistical change. Thus, it was not possible to confirm this improves the lipid fraction in all age groups. Only men between 30 and 40 years showed significant improvements in this fraction of cholesterol in both short and long-term.

The absence of information concerning the practice of regular exercise after surgery may be a large bias in the studies with long follow-ups after surgery. The regular practice of physical exercise has the ability to improve the levels of this lipid fraction ${ }^{(48)}$.

Therefore, we cannot claim to be independent effect of surgery the improvement in levels of lipid fractions, especially HDL cholesterol. Observing the values of normality of this fraction, we found a higher prevalence of women with levels below the reference values. It is important to emphasize that the decrease after surgery was not significant, but as baseline values were in limit of normality and some age groups achieved mean values less than proposed reference. This outcome may suggest that in a longer follow-up, values may decrease significantly below normal, increasing cardiovascular risk.

Morbid obesity in association with dyslipidemia are important factors to the development of atherosclerosis and heart disease, so the reduction in body weight associated with improvement of lipid profile can reduce the risk of cardiovascular events in this population.

After gastric bypass, we observed a decrease in the prevalence of hypertensive patients. Before surgery, blood hypertension assailed $53.66 \%$ of the patients selected for the study. In the short term this prevalence decreased significantly to $35.12 \%$ and did not changed between short and long term. Also it was not observed a rebound in individuals with hypertension at baseline. Preview studies indicate that the reduction in blood pressure seems to be transient ${ }^{(8,18,43)}$. The influence of increased secretion of GLP-1 resulting in increased renal activity and increased diuresis is an important mechanism in this transient reduction in blood pressure associated with a reduction of visceral fat ${ }^{(21)}$.

The gastric bypass roux-Y appeared to be as an important tool in decreasing the metabolic syndrome parameters. The reduction of body mass accompanied to decrease insulin resistance resulted in lower prevalence of comorbidities associated with obesity. The benefits were extended to all age groups and both genders.

Andrade-Silva SG, Caranti DA, Sallet JA, Leal LPFF, Leal AJF, Dâmaso AR. Idade e gênero podem influenciar nos resultados da derivação gástrica em Y de Roux? Parâmetros da síndrome metabólica. Arq Gastroenterol. 2014,51(3):171-9.

RESUMO - Contexto - A obesidade severa favorece o desenvolvimento de doenças graves, como hipertensão, diabetes mellitus, aterosclerose e esteatose hepática. Na última década, houve um aumento de procedimentos bariátricos no Brasil. Objetivos - O objetivo deste estudo foi verificar se o gênero e a idade no momento da cirurgia implicam em diferenças significativas nos parâmetros da síndrome metabólica. Métodos - Estudo envolveu 205 prontuários de pacientes adultos submetidos à derivação gástrica em Y-de-Roux, estratificada por gênero e faixas etárias, acompanhados por equipe multidisciplinar com seguimento de 1 ano. Resultados - Observou-se diminuição significativa do índice de massa corporal, glicemia e insulina em todas as idades e ambos os gêneros. O perfil lipídico apresentou melhorias significativas, exceto na fração da lipoproteína de alta densidade. Os níveis de gordura ectópica no fígado diminuíram depois de 6 meses. Houve uma diminuição na prevalência de hipertensos 6 meses após a intervenção cirúrgica. Conclusão - A derivação gástrica em Y-de-Roux mostrou melhora dos parâmetros da síndrome metabólica. A redução da massa corporal acompanhada da diminuição na resistência à insulina resultou em menor prevalência de comorbidades associadas à obesidade. Os benefícios foram similares e estenderam-se para ambos os gêneros e todas as faixas etárias entre 18 e 65 anos de idade.

DESCRITORES - Cirurgia bariátrica. Síndrome X metabólica. Anastomose em-Y de Roux. Fígado gorduroso. 


\section{REFERENCES}

1. Ahmed AR, Rickards G, Coniglio D, Xia Y, Johnson J, Boss T, O’Malley W. Laparoscopic Roux-en-Y gastric bypass and its early effect on blood pressure. Obes Surg. 2009;19:845-9.

2. Ashrafian H, Athanasiou T, Li JV, Bueter M, Ahmed K, Nagpal K, et al. Diabetes resolution and hyperinsulinaemia after metabolic Roux-en-Y gastric bypass. Obes Rev. 2011;12:e257-72.

3. Asztalos BF, Swarbrick MM, Schaefer EJ, Dallal GE, Horvath KV, Ai M, Stanhope KL, et al. Effects of weight loss, induced by gastric bypass surgery, on HDL remodeling in obese women. J Lipid Res. 2010;51:2405-12.

4. Cotrim HP, Alves E, Almeida AM, Barbosa DB, Santos AS, Lobo AP, et al. Doença hepática gordurosa não alcoólica: características clínicas e histológicas em obesos graves submetidos à cirurgia bariátrica. Acta Gastroenterol Latinoam. 2007;37:224-230

5. Brasil, Ministério da Saúde. Pratique saúde. [cited 2012 Feb 10]. Available from: www.dtr2001.saude.gov.br/pratique_saude/diabetes.htm

6. Buchwald H, Avidor Y, Braunwald E, Jensen MD, Pories W, Fahrbach K, Schoelles K. Bariatric surgery: a systematic review and meta-analysis. JAMA. 2004;292:1724-37.

7. Buchwald H, Estok R, Fahrbach K, Banel D, Jensen MD, Pories WJ, et al. Weight and type 2 diabetes after bariatric surgery: systematic review and meta-analysis. Am J Med. 2009;122:248-256.

8. Carrasco F, Papapietro K, Csendes A, Salazar G, Echenique C, Lisboa C, et al Changes in resting energy expenditure and body composition after weight loss following Roux-en-Y gastric bypass. Obes Surg. 2007;17:608-16.

9. Castro Cesar M, de Lima Montebelo MI, Rasera I Jr, de Oliveira AV Jr, Gomes Gonelli PR, Aparecida Cardoso G. Effects of Roux-en-Y gastric bypass on resting energy expenditure in women. Obes Surg. 2008;18:1376-80.

10. Chan HL, de Silva HJ, Leung NW, Lim SG, Farrell GC; Asia-Pacific Working Party on NAFLD. How should we manage patients with non-alcoholic fatty liver disease in 2007? J Gastrenterol Hepatol. 2007;22:801-8.

11. Coppini LZ, Bertevello PL, Gama-Rodrigues J, Waitzberg DL. Changes in Insulin in Morbidly Obese Patients with or without Metabolic Syndrome after Gastric Bypass. Obesity Surgery. 2006.16(11):1520-5.

12. Costa ACC, Ivo ML, Cantero WB, Tognini JRF. Obesidade em pacientes candidatos a cirurgia bariátrica. Acta Paul Enferm. 2009;22:55-9.

13. Cruz Filho RA, Corrêa LL. O papel da glicemia capilar de jejum no diagnóstico precoce do diabetes mellitus: correlação com fatores de risco cardiovascular. Arq Bras Endocrinol Metabol. 2002;46:255-9.

14. Cunha LCBP, Cunha CLP, Souza AM, Chiminacio Neto N, Pereira RS, Suplicy HL. Estudo ecocardiográfico evolutivo das alterações anátomo-funcionais do coração em obesos submetidos à cirurgia bariátrica. Arq Bras Cardiol. 2006;87:612-22.

15. Dufour F, Champault G. Is bariatric surgery in adolescents appropriate? J Chir (Paris). 2009;146:24-9.

16. Faintuch J, Marques PC, Bortolotto LA, Faintuch JJ, Cecconello I. Systemic inflammation and cardiovascular risk factors are morbidly obese subjects different. Obes Surg. 2008;18:854-62

17. Fisher BL. Schauer P. Medical and surgical options in the treatment of severe obesity. Am J Surg. 2002;184:9-16.

18. Frank P, Crookes PF. Short and long-term surgical follow-up of the postbariatric surgery patient. Gastroenterol Clin North Am. 2010;39:135-46.

19. Friedewald WT, Levy RI, Fredrickson DS. Estimation of the concentration of low-density lipoprotein cholesterol in plasma without use of the preparative ultracentrifuge. Clin Chem. 1972;18:499-502.

20. Geloneze B, Tambascia MA. Laboratorial evaluation and diagnosis of insulin resistance. Arq Bras Endocrinol Metab. 2006;50(2):208-15.

21. Gutzwiller JP, Hruz P, Huber AR, Hamel C, Zehnder C, Drewe J, et al. Glucagon-like peptide-1 is involved in sodium and water homeostasis in humans. Digestion. 2006;73:142-5.

22. Hrebícek J, Janout V, Malincíková J, Horáková D, Cízek L. Detection of insulin resistance by simple quantitative insulin sensitivity check index QUICKI for epidemiological assessment and prevention. J Clin Endocrinol Metab. 2002;87:144-7.

23. Jamal M, Wegner R, Heitshusen D, Liao J, Samuel I. Resolution of hyperlipidemia follows surgical weight loss in patients undergoing Roux-en-Y gastric bypass surgery: a 6-year analysis of data. Surg Obes Relat Dis. 2011;7:473-9.

24. Kashyap SR, Daud S, Kelly KR, Gastaldelli A, Win H, Brethauer S, et al. Acute effects of gastric bypass versus gastric restrictive surgery on beta-cell function and insulinotropic hormones in severely obese patients with type 2 diabetes. Int J Obes. 2010;34:462-71.

25. Katz A, Nambi SS, Mather K, Baron AD, Follmann DA, Sullivan G, Quon MJ. Quantitative Insulin Sensitivity Check Index: a simple. accurate method for assessing insulin sensitivity in humans. J Clin Endocrinol Metab. 2000;85:2402-10.
26. Laferrère B, Heshka S, Wang K, Khan Y, McGinty J, Teixeira J, et al. Incretin levels and effect are markedly enhanced 1 month after Roux-en-Y gastric bypass surgery in obese patients with Type 2 diabetes. Diabetes Care. 2007; 30:1709-16.

27. Laferrère B, Teixeira J, McGinty J, Tran H, Egger JR, Colarusso A, et al. Effect of weight loss by gastric bypass surgery versus hypocaloric diet on glucose and incretin levels in patients with type 2 diabetes. J Clin Endocrinol Metab. 2008;93:2479-85.

28. Lee S, Jin Kim Y, Yong Jeon T, Hoi Kim H, Woo Oh S, Park Y, Soo Kim S. Obesity is the only independent factor associated with ultrasound-diagnosed non-alcoholic fatty liver disease: a cross-sectional case-control study. Scand J Gastroenterol. 2006;41:566-72.

29. Lohman TG, Roche AF, Martorrel R. Anthropometric Standardization Reference Manual. Human Kinetic/Books. Illinois. 1988.

30. Matthews DR, Hosker JP, Rudenski AS, Naylor BA, Treacher DF, Turner RC. Homeostasis model assessment: insulin resistance and b-cell function from fasting plasma glucose and insulin concentrations in man. Diabetologia. 1985; 28:412-9.

31. Monteiro Júnior Fd, Silva Júnior WS, Salgado Filho N, Ferreira PA, Araújo GF, Mandarino NR, et al. Effects of Weight Loss Induced by Bariatric Surgery on the Prevalence of Metabolic Syndrome. Arq Bras Cardiol. 2009;92:452-6.

32. Morais AA, Faintuch J, Leal AA, Noe JA, Bertollo DM, Morais RC, Cabrini D. Inflammation and biochemical features of bariatric candidates: does gender matter? Obes Surg. 2011;21:71-7.

33. Musso G, Gambino R, Bo S, Uberti B, Biroli G, Pagano G, Cassader M. Should nonalcoholic fatty liver disease be included in the definition of metabolic syndrome? A cross-sectional comparison with Adult Treatment Panel III criteria in nonobese nondiabetic subjects. Diabetes Care. 2008;31:562-8.

34. Nguyen NT, Varela E, Sabio A, Tran CL, Stamos M, Wilson SE. Resolution of hyperlipidemia after laparoscopic Roux-en-Y gastric bypass. J Am Coll Surg. 2006;203:24-9.

35. O'Keefe KL, Kemmeter PR, Kemmeter KD. Bariatric surgery outcomes in patients aged 65 years and older at an American Society for Metabolic and Bariatric Surgery Center of Excellence. Obes Surg. 2010;20:1199-205.

36. Okosun IS, Chandra KM, Boev A, Boltri JM, Choi ST, Parish DC, Dever GE Abdominal adiposity in U.S. adults: prevalence and trends.1960-2000. Prev Med. 2004;39:197-206.

37. Ribeireiro T, Swain J, Sarr M, Kendrick M, Que F, Sanderson S, et al. NAFLD and insulin resistance do not increase the risk of postoperative complications among patients undergoing bariatric surgery - a prospective analysis. Obes Surg. 2011;21:310-5

38. Rubino F, Forgione A, Cummings DE, Vix M, Gnuli D, Mingrone G, et al. The mechanism of diabetes control after gastrointestinal bypass surgery reveals a role of the proximal small intestine in the pathophysiology of type 2 diabetes. Ann Surg. 2006;244:741-9.

39. Sauerland S, Angrisani L, Belachew M, Chevallier JM, Favretti F, Finer N, et al. Obesity surgery: evidence-based guidelines of the European Association for Endoscopic Surgery (EAES). Surg Endosc. 2005;19:200-21.

40. Schauer PR, Burguera B, Ikramuddin S, Cottam D, Gourash W, Hamad G, et al. Effect of laparoscopic Roux-en Y gastric bypass on type 2 diabetes mellitus. Ann. Surg. 2003;238:467-84; discussion 84-5.

41. Silvestre V, Ruano M, Domínguez Y, Castro R, García-Lescun MC, Rodríguez A, et al. Morbid obesity and gastric bypass surgery: biochemical profile. Obes Surg. 2004;14:1227-32.

42. Sjöström L, Lindroos AK, Peltonen M, Torgerson J, Bouchard C, Carlsson B, et al. Lifestyle. diabetes. and cardiovascular risk factors 10 years after bariatric surgery. N Engl J Med. 2004;351:2683-93.

43. Sjöström L, Narbro K, Sjöström CD, Karason K, Larsson B, Wedel H, et al. Effects of bariatric surgery on mortality in Swedish obese subjects. N Engl J Med. 2007;357:741-52.

44. Te Sligte K, Bourass I, Sels JP, Driessen A, Stockbrugger RW, Koek GH. Non-alcoholic steatohepatitis: review of a growing medical problem. Eur J Intern Med. 2004; $15: 10-21$

45. Third report of the National Cholesterol Education Program (NCEP) expert panel on detection, evaluation, and treatment of high blood cholesterol in adults (Adult Treatment Panel III) final report. Circulation. 2002;106:3143-421. (NÃO TEM AUTOR)

46. Tock L, Prado WL, Caranti DA, Cristofalo DM, Lederman H, Fisberg M, et al. Nonalcoholic fatty liver disease decrease in obese adolescents after multidisciplinary therapy. Eur J Gastroenterol Hepatol. 2006;18:1241-5.

47. Van der Laar A, Caluwé L, Dillemans B. Relative Outcome Measures for Bariatric Surgery. Evidence Against Excess Weight Loss and Excess Body Mass Index Loss from a Series of Laparoscopic Roux-en-Y Gastric Bypass Patients. Obes Surg. 2011;21:763-7. 
48. Varady KA, Bhutani S, Klempel MC, et al. Comparison of effects of diet versus exercise weight loss regimens on LDL and HDL particle size in obese adults. Lipids Health Dis. 2011;10:119.

49. Wang Y, Zhang C. Bariatric surgery to correct morbid obesity also ameriolates atherosclerosis in patients with type 2 diabetes mellitus. Am J Biomed Sci. 2009;1:56-69.

50. Warnick GR, Knopp RH, Fitzpatrick V, Branson L. Estimating low-density lipoprotein cholesterol by the Friedewald equation is adequate for classifying patients on the basis of nationally recommended cutpoints. Clin Chem. 1990;36:15-9.

51. Welbourn R, Pournaras D. Bariatric surgery: a cost-effective intervention for morbid obesity; functional and nutritional outcomes. Proc Nutr Soc. Proceedings of the nutrition society. 2010;69:528-35.
52. WHO. World Health Organization. Obesity and overweight. 2011. [cited 2011 Feb 02]. Available from: http://www.who.int/mediacentre/factsheets/fs $311 / \mathrm{en} /$ index.html.

53. Wickremesekera K, Miller G, Naotunne TD, Knowles G, Stubbs RS. Loss of insulin resistance after Roux-en-Y gastric bypass surgery: a time course study. Obes Surg. 2005;15:474-81.

54. Willkomm CM, Fisher TL, Barnes GS, Kennedy CI, Kuhn JA. Surgical weight loss $>65$ years old: is it worth the risk? Surg Obes Relat Dis. 2010;6:491-6.

Received 4/2/2014

Accepted 7/4/2014 